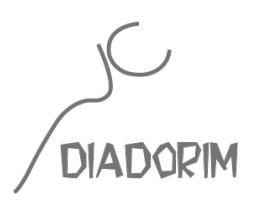

\title{
EURASIAN DYNAMICS AND PARADOXES OF THEIR HYBRIDITY IN SOUTHERN CHINA. DINÂMICAS
}

\author{
EUROASIÁTICAS E PARADOXOS DE SUA HIBRIDEZ \\ NO SUDESTE DA CHINA
}

\author{
Maria Célia Lima-Hernandes ${ }^{1}$ \\ Roberval Teixeira e Silva ${ }^{2}$
}

\begin{abstract}
In this article, we propose to discuss linguistic identities in Macao, considering some data collected from the Macao Historical Archives. The purpose of this article is to return to this discussion already rehearsed in other moments of our studies (LIMA-HERNANDES 2010, 2015, 2016; TEIXEIRA-E-SILVA \& LIMA-HERNANDES 2010, 2014, 2015; LIMA-HERNANDES \& TEIXEIRA-E-SILVA 2012, 2017; LIMA-HERNANDES, CARVALHINHOS \& TEIXEIRA-E-SILVA 2014; TEIXEIRA-E-SILVA, LIMA-HERNANDES \& ALMEIDA 2012; among others). This work is based on a more extended dimension into the concept of Macanese identities, obtained through access to new documents, together with the assumption that Macanese communities aligned over time until 1999, building a hybrid identity in their social actions. However, since then, the direction of this movement has been gradually changing to meet the new projects of life in Macau. The goal herein is to demonstrate that, despite the perceived fluctuation of identities in the conversations and reports, there is a change in the conception of what Macao and its community are. We have argued that the Yin and Yang paradoxes, used by Givón (2005) to explain the movements of language change, contextually reveal a powerful tool to the understanding of movements within hybrid communities.
\end{abstract}

KEYWORDS: Sociolinguistic Identity; Macanese History; Yin and Yang paradoxes.

\footnotetext{
1 Professora da Universidade de São Paulo. Universidade de Macau. Arquivo Histórico de Macau. CNPq. FAPESP.

2 Department of Portuguese. Universidade de Macau.
}

\section{(cc)BY-NC}




\section{RESUMO}

Neste texto, propomo-nos a discutir identidades linguísticas em Macau, considerando alguns dados coletados no Arquivo Histórico de Macau. O propósito em retomar a essa discussão já ensaiada em outros momentos de meus estudos (LIMA-HERNANDES 2010, 2015, 2016; TEIXEIRA-E-SILVA e LIMA-HERNANDES 2010, 2014, 2015; LIMA-HERNANDES e TEIXEIRA-E-SILVA 2012, 2017; LIMA-HERNANDES, CARVALHINHOS \& TEIXEIRA-ESILVA 2014; TEIXEIRA-E-SILVA, LIMA-HERNANDES \& ALMEIDA 2012; dentre outros) assenta-se na dimensão mais estendida ao conceito de identidade macaense que pudemos alcançar, efeito do acesso a novos documentos. Partimos do pressuposto de que as comunidades macaenses alinharam-se ao longo do tempo até 1999, construindo uma identidade híbrida $t$ em suas práticas sociais. A direção desse movimento, no entanto, foi gradativamente mudando para atender aos novos projetos de vida em Macau. É objetivo demonstrar que, a despeito das flutuações identitárias percebidas nas conversas e relatos, há uma mudança de concepção do que seja Macau e sua comunidade. Evidenciamos que os paradoxos Yin e Yang, empregados por Givón (2005) para explicar os movimentos de mudança nas línguas, revela-se, nesse enquadramento contextual, poderoso auxiliar para a compreensão de movimentos de comunidades híbridas.

PALAVRAS-CHAVE: Identidade Sociolinguística; História Macaense; Paradoxos Yin e Yang.

\section{Introduction}

The whole course of a community, their movements and interactions constitute clues that allow the reconstitution of its linguistic history. When we risk retelling the social history of Macao, now known as the Macao Special Administrative Region (MSAR), we run the risk of drawing a peculiar historical picture of a deictic place, influenced always by the identities of the analyst him/herself. Even more so, will be this access a barrier when considering the young Macanese, who are constructing the most recent social history of Macao. To consider the situation of a community with its history and culture, and the relationship that this situation produces in the current sociolinguistic coexistence, constitutes the core of the work of language policies.

Considering that the languages of the land (official, maternal and inherited) respond to the variables governing the general policies dictated in the region, means to be aware that forces (here identified as sociolinguistic identities, school and inherited languages) constitute opposing movements and seemingly contradictory ones that act to reconcile what is diverse by historically recurrent mechanisms (Yin and Yang paradox: GIVÓN, 2005). This paradox is summed up in the idea that, if differences act to disintegrate the sociolinguistic system, still more cohesion will prove systemic.

Therefore, it is an ingenuity through which the speaker is impelled to be expressive and innovative, but he does so in accordance with rules of inter-comprehension. The formula adopted by the person will align intuition and memory according to the discourse-pragmatic repertoire of the interlocutor. From this action, discursive practices would emerge outside the context (paradox of diffuse attention), giving the impression that the disparity manifests itself, 
but instead, the speaker would make the decision for what is more productive and more frequent in her/his language (paradox of rooting and ease).

By adopting recurring patterns of use for atypical contexts, the speaker would reanalyze constructions (paradox of practice out of context), offering an already known response in unknown syntactic contexts, from which new words and innovative constructions would emerge. These are the contexts in which conception and language can change, but this change must nonetheless be perceived as an attempt to survive the existing system, already mixed with traces of the novelties imposed in daily life. This ingenuity is reflected in the Macao society in various periods of its history.

To perform the study, we used two record sources. The record documents refer to the last two years of the 19th century and the first ten years of the 20th century. All interviews and reports were recorded during the two field work periods held between 2010-2011 3 and 2015-2016 ${ }^{4}$, respectively, in Macao ${ }^{5}$. Through this documentation, it was possible to notice a change of behavior between the generations of Chinese inhabitants of Macao. This same finding was reported by Sing (1997), who mentioned differences in professional performance, especially in the formal education time, dowries and rituals in marriages. In fact, throughout our visits to study in Macau, we have noticed the resilience of traditional Chinese habits (customary practices), such as visiting temples, attending Chinese operas, and eating, among others. But there is a change that called our attention: how the heirs are named.

The element that marked this change was the Handover in 1999, which dictated the political guidelines of the region, strongly influenced by unusual customs practiced until then in Macao, at least for those who had a closer contact with the Portuguese and Macanese administration. In the moments prior to the realization of this change of sovereignty in Macao, the idea that the Chinese of Macao followed the plan to have their children get married with Chinese from the mainland or Macao has already been verified (SING, 1997). The prestige embedded in this idea became stronger, since the future of the Eurasians was even more uncertain in Macanese lands. Let us remember that until recently, the rejection of this idea was a fact. Chinese were then the least prestigious community during the Portuguese rule, although real power over Macao was already emanating from the Chinese regarding various instances, including commerce in general, from clothing to food, basic needs in a place where effectively there is not plantations or animal husbandry to supply the population.

At the time of the Handover, 57.1\% of the parents interviewed stated that the official language of Macao should be Chinese, but did not specify whether Chinese was to be Cantonese, Mandarin or some other Chinese language. However, of the children interviewed,

3 Project supported by CAPES.

4 Project supported by CNPQ.

5 We are very thankful to the Macau Historical Archive.

Diadorim, Rio de Janeiro, vol. 21, Especial, p. 186-199, 2019. 
21.4\% chose Cantonese as the exclusive language of Macao. These responses could only be a representation of a still distant moment of the reality of change of sovereignty, but it is not what is demonstrated by the attitudes of the young couples (with the configuration "Chinese + Macanese") and of the elderly Macanese parents from the last field research previously mentioned (LIMA-HERNANDES, 2011).

In that foray, it was possible to verify that the young couples had a preoccupation with the baptismal name of their offspring. Macanese grandparents also revealed their concern for the school and education of their grandchildren, directing their children, sons-in-law and daughters-in-law to identify Chinese-sounding syllables in the names to be chosen, as well as enrolling them in schools where they could learn Chinese, something unthinkable during most of the $20^{\text {th }}$ century.

\section{A deeper understanding of the ascension dynamics among the Macanese}

Several studies portray the Macanese society during the Portuguese administration (REGO 1950; GALVÃO and SELVAGEM 1953; TEIXEIRA 1994a, 1994b; FORJAZ 1994; MORBEY 1994; SILVA 1997; GALANTE 1999; GASPAR 2014; AMARO 1994a; 1994b; AZEVEDO 1984). How a change of intentions occurred in Macanese society was something that intrigued us while editing documents, deciphering birth certificates, death certificates and wills, or even listening to the reports of the research participants. Throughout the studies, we joined other researchers so that the reflection gained in different perspectives from ours.

LIMA-HERNANDES, CARVALHINHOS \& TEIXEIRA-E-SILVA (2014) was one of these partnerships, where we studied the ways of naming Macanese in the first decade of the $20^{\text {th }}$ century and the decision for a Western name in general was evident in Macao. In the documentation we collected as a sample for the first ten years of the twentieth century and initially restricted to the community of Santo António, we became aware that the baptismal name was the first step towards the social inclusion of children. The second step bifurcated into one of two decisions, mainly for the girls: marriage or the monastic life. We decided to focus on this first step to deepen our understanding of existing contextual motivations and pressures.

At that moment, it was necessary to inquire about the origin of these children and the motivation of so many orphans in such a small city. In an individual investigation into the facts of everyday life in Macao, we discovered that by the end of the 19th century, around 1895, an epidemic of bubonic plague struck Macao. Only between 1885 and 1951, 65,000 children found shelter in the Asilo da Santa Infância.

At the dawn of the twentieth century, the number of Chinese orphans was enormous. Due to the parallel reading of several other documents of the period, we concluded that there is a relationship between these facts and the stories reported by participants in our research. Older 
people reported that the mother was of Chinese origin, but most of that origin was not registered in the mother's name. In their names, they kept exclusively the surname of the family of the father, who was of Macanese origin (that is, son of Portuguese with an Asian mother).

From reports collected in historical documents, it was learned that orphaned Chinese girls were left at the door of the asylum and, after being welcomed, they were baptized in the Parish of Santo António, which at that time was the most Chinese-oriented parish in Macao, with no access to the services and benefits of the city. Besides these, there were those who were "rescued" by Macanese and later baptized as adults, whereupon they ceased to be invisible in the history of society.

In the baptism documents we edited, we found that these children and young women were given names, but not surnames. On the other hand, some Macanese, not from an elite power, had names associated with the Catholic religion, usually the name of the saint of the day. Knowing the history of this group became the first interest of our research. Thus, the divergent way of conceiving the space of coexistence calls for analyzing the name from various perspectives. One is that which refers to cultural distance. This distance can be read historically by the riots in Macao against the Portuguese (and Macanese).

In 1966, the Chinese, excluded from their right to have an Eastern cultural education, sought a license to build a Chinese school on Taipa Island. Since they did not succeed through legal channels, they began to construct it anyway. The police were sent and violently apprehended everyone without distinction. The Chinese press and associations linked to China began to attack the Macao government as a form of protest. The sense of revolt grew uncontrollably and, with the mobilization of the entire Chinese community, was influenced by the nationalist sentiments of the Cultural Revolution, whereupon the Beijing authorities took a favorable part in the revolt. It is true that this riot shows us that many were those who did not submit to the Portuguese or Macanese government, asserting their Chinese identity in their actions and social engagements.

Sociocognitivists know that the whole movement of the body is reflected in the language. It is true that the onomastic processes (CARVALHINHOS and ANTUNES, 2007; CARVALHINHOS, 2011) can be explained by these movements. From these movements, we understand that the dynamics reflect different group identities and that they coexist in a tiny space of land. From a broader perspective, one can analyze the name in two cultural spheres. A first implies the geographical association of individuals, which favors the assumption of the cultural identification of a being, while the second, considers that the graphical boundaries have become less noticeable, given the shifts in borders, and so too the adoption of names seems flexible.

The internet, television, movies, and the entire cultural framework make names virtually migrate and be targeted for evaluation, producing rejection or incorporation into groups, giving 
temporal cohesion to the choices. In a motivating microsphere, there is the one that instantiates a personal subjective projection in the children by the one who chooses how they will be named (usually the parents), creating a symbolic one by means of the chosen name, or even originating from a safe harbor that can guarantee success to the loved one at the time he/she is baptized. This second bias allows us to analyze (albeit briefly) the aforementioned in order to ensure that a secure future can be assumed from a choice of name; thus, baptism would be valued as a VIP ticket in another culture.

Unlike Western names, most Chinese names may come from numerous classes of words and not exclusively from the noun / adjective binomial. And in this logic, the reasons that govern the choice of the names of the children may be very different from those already mentioned. The name may bear, for example, a symbolic meaning of what is to come, as in ancient Western societies. In this way, it is common to find anthropomorphs related to ambitions, professions admired by the parents, desire for longevity and good health, patriotism, desire for wealth, happiness, intelligence, physical beauty and high moral. The Chinese orphans of Macao, however, received names chosen according to quite a different logic, as we have already explained.

With this brief exposition, it seems clear that the whole cultural panorama that involves the choice of a name can preserve differences and peculiarities derived not only from the local language, but also from identity linings that reflect on cultural significance. In the first decade of the $20^{\text {th }}$ century, the choice of a Portuguese name represented the project of socio-cultural insertion initiated by the Catholic sacraments and by the erasure of ethnic names. In addition, the adoption of a Western name generated, at the beginning of the $20^{\text {th }}$ century, the emptying of the sense of belonging to a group and camouflage of ethnic bonding (despite obvious physical traits).

Some conservative forces coexisted in this space of struggles for domination and power. This place of sociocultural relevance competed with the Chinese culture (hence, its Cantonese language), millennial in Eastern history, always rooted in daily life to actions and values, native beliefs and even in the projection it had in the language described by Batalha (1988a, 1988b). Portuguese culture, considered a foreigner one, was a teenager in the spatial context because it could hardly manage that space it considered a "colony", although it had imported an administrative apparatus that could be "efficient". Except for a few confrontations, the impasse between these two groups was very invisible during the 400 years of Portuguese administration, coming to the forefront, more robustly, in three historical adventures: the death of Ferreira do Amaral and Mesquita; later, the reorganization of China in the post-mortem period of Mao Tse Tung; and the approach of Handover. It is at this moment that they accept, although with few restrictions: (i) the coexistence of Catholic practices alongside Chinese rituals and rites; (ii) the incorporation of Chinese as a Catholic mass language in traditionally Chinese communities, such as Santo António; (iii) the peaceful coexistence of Chinese and Portuguese 
sections in schools, admitting dialogues in English as a form of inter-comprehension; and (iv) the division of powers and public administrative services between Chinese and Macanese.

Having fulfilled this stage of acceptance of the differences and empowerment of Chinese who did not know Portuguese, some consequences already planned by the new government came to be as a rule: (i) the rise of Mandarin in South China, via the use of a general label "Chinese", with teachers teaching Mandarin; (ii) the transmission of all contents in Chinese and not only in the Chinese language classes; (iii) the Portuguese school begins to lose students and starts to make plans to welcome Chinese students ${ }^{6}$; (iv) bookstores linked to the Macao government still have books in Portuguese on their shelves.

By 2015, this picture was already altered in the following aspects: (i) schooling is becoming more and more organized in Mandarin; (ii) bookstores linked to the Macao government have much less copies of books in Portuguese; (iii) the Chinese returnees, especially from the United States, occupy prominent positions at the University of Macau, a traditional Portuguese stronghold.

All these actions differ from those adopted in the early $20^{\text {th }}$ century, when: (i) Portuguese was practically the only language in the administration; (ii) the social occidentalization of young women through marriage and renaming was promoted; (iii) the Chinese and the Portuguese people were separated in different groups and schools, depending on the adopted family policy and the ties with the Portuguese culture; (iv) Eurasian/ Chinese marriages implied low prestige for the Macanese.

The strategies adopted in the early $20^{\text {th }}$ century and after the Handover are the same: revision of family design of choices and ethnic identity bonding. Let us look at the following tables:

Table I: Unmarried, natural Chinese girls from mainland China, daughters of unknown Chinese parents

\begin{tabular}{|l|l|l|}
\hline Birthdate & Baptismal name & Age \\
\hline 01.20 .1900 & Maria & 80 \\
\hline 03.06 .1903 & Maria José & 24 \\
\hline 06.29 .1900 & Maria Magdalena & 19 \\
\hline 09.22 .1900 & Maria & 18 \\
\hline
\end{tabular}

(LIMA-HERNANDES, CARVALHINHOS E TEIXEIRA E SILVA, 2014)

Table II: Macao's unmarried girls, the daughter of Chinese parents

\begin{tabular}{|l|l|l|}
\hline Birthdate & Baptismal name & Age \\
\hline 08.14 .1901 & Ritta Alan (Alau?) & 16 \\
\hline 02.27 .1903 & Agueda Alan (Alau?) & \\
\hline 11.18 .1904 & Anna Mac & 16 \\
\hline
\end{tabular}

(LIMA-HERNANDES, CARVALHINHOS E TEIXEIRA E SILVA, 2014)

6 About this, cf. Rocha (2010).

Diadorim, Rio de Janeiro, vol. 21, Especial, p. 186-199, 2019. 
Table III: single girl, Canossian religious

\begin{tabular}{|l|l|l|}
\hline Birthdate & Baptismal date & Age \\
\hline 08.15 .1909 & Maria Augusta & 26 (filha de chinas) \\
\hline 05.17 .1913 & Silvestra Lopes & 37 \\
\hline
\end{tabular}

(LIMA-HERNANDES, CARVALHINHOS \& TEIXEIRA E SILVA, 2014)

It is important to note that in the Parish of Santo António, the date of registration in this period rarely equaled the birth date of the individual. The best date for baptism was determined by a vacancy in the parish and sisters' agenda, except for cases where the individual's health condition was very serious. The baptisms were collective. These records make it possible to verify that no individual had a surname or was entitled to receive one during the baptismal ceremony but had the right to have a godmother or godfather (the sponsors).

Let us remember that in this context, being Catholic provided a high index of social inclusion. The more 'dignified' the sponsor, the greater the individual's luck in having access to citizen rights.

\section{Relationship between names and identities in Macao}

Some criteria allow to establish action patterns, namely, the sponsor's status and the baptismal name, which separates individual members of the group whose parents are unknown. A survey like this allows to recognize changes in the social patterns of behavior in Macao.

The results led us to note that female philanthropic participation was already very present, and the agents were people who had already undergone a similar process of social inclusion? The attitude of these women was fundamental for other citizens of Macao to awaken to the cause, making it more visible and paving the way for a normalization and extension of this practice to the ordinary citizens of Macao.

In addition, the strategy of assigning surnames or two names appears, one of which would be re-examined in the future as a surname. Here are some examples:

a) Luzia Petronilla $<$ Petronilla Tam $>$ Sister Petronilla

The baptized was called Luzia Petronilla because her godmother was Petronilla Tam, a Canossian sister of Chinese origin. She, in turn, was baptized Petronilla for having had as godmother Sister Petronilla, born in Italy.

b) Firmina Filippa $<$ Filippa Cian $>$ Sister Filippa, native of China.

The baptized was named Firmina Filippa, for having had as godmother Filippa Cian, baptized, in turn by the sister Filippa, native of China, but part of the order of Ca-

7 About godmothers and her actions, cf. Teixeira e Silva \& Lima-Hernandes, 2012.

Diadorim, Rio de Janeiro, vol. 21, Especial, p. 186-199, 2019. 
nossian sisters.

c) Thereza Angelina < Maria Thereza Manhão

The baptized was called Thereza Angelina, for having been baptized by Maria Thereza Manhão, who is a Macanese of a traditional family in Macao, although she was born Chinese and lived in the home of the Canossians.

d) Thereza Francisca $<$ Francisca Athôn

The baptized was called Thereza Francisca, due to having had Francisca Athôn as godmother, former inhabitant of the home of the Canossians, who had married and started to help others with similar history.

Something, however, is changing in the communities of Macao and this is a sneaky change: among many Macanese, it is evident now the tendency to attach with Chinese cultures and one consequence is choosing Chinese names. To feel the weight of these attitudes will depend on living longer in the $21^{\text {st }}$ century: this evidence already occurs in the family activities of the grandparents and parents, who care about the future of their offspring and descendants in a space that is increasingly dominated by Chinese languages and cultures and by the interference of China's central power.

Responses to this concern range from official language teaching documents to the choices of children's schools in order to master Chinese writing. And as Margarida, a Macanese grandmother, says: “(...) if one wants to continue in Macao, one must have the Chinese name to have the connection ..." (she refers to the daughter -in-law and the name of her grand-daughter, which in 2011 was about to be born) (LIMA-HERNANDES \& TEIXEIRA-E-SILVA, 2010, p. 47). Thus, others do the same. In the sonority of the syllables, they look for the necessary bond to be linked to the Chinese ethnic group.

\section{Handover effects on sociolinguistic identity}

At the time of the Handover, there were some policies in order to respect the identity's choices of the Macao's inhabitants. Each one made the decision to be linked to the Chinese ethnicity or the Portuguese one. Most of the Macanese ratified their desire to remain attached to the Portuguese group. They divested themselves of assets, collected money and bought property in Portugal.

However, while in Portugal, they found out through contact with the Portuguese that the perception of themselves could be mistaken. In fact, they were considered Chinese. Their nationality was questioned, and their brio was shaken by the Portuguese who could not understand that an individual with oriental appearance could be speaking Portuguese. For many, 
the situation was so impressive that some returned to Macao after the dust subsided and decided to take their Macanese place and admit their dual identity in some cases and their Chinese identity, despite the Portuguese passport.

Those who already had family in Portugal did not feel this rejection. They continued there, and the Macanese identity's traits are even stronger. The Macanese who affirmed their Chinese identity continued in the project of socio-political participation. Time will tell if their actions still conform them in their Portuguese hereditary bases.

The participants of the survey, who agreed to talk about the theme even though at the time this was a social taboo, referred to a certain fear of the change of political system in Macao. They feared for their descendants, but they were convinced that the change would not affect themselves because of their age group. They felt, however, that it was a matter of survival to have a "card up the sleeve" since the vision of a "communist" China was frightening to the Macao people: they knew the effects of the Cultural Revolution in China and the condition of those who asked for shelter in Macao. The news they heard at the time, on the other side (after the Gate of Siege), did not encourage prospects.

On the other hand, the news of the effects in Hong Kong, post-Handover, calmed their hearts. At the time of the inquiries, Hong Kong lived in complete peace with the giant neighbor and people did not realize that a siege was being organized, but not a physical one. There was already a move to occupy the seats in the legal decision positions also in Hong Kong. The news in Hong Kong from 2010 onwards was blamed for relating the story of the real resumption of control by the central government.

This perspective can be grasped from reading the account of Bernardo da Silva, a Macanese and former teacher of the Pedro Nolasco Commercial School. He wondered about his origin when it was, indeed, far from Macao. He was a man outside his original space, but in his words he showed the difference that distinguished him from the Chinese: "Macanese have always lived with the Chinese inside and outside their borders" and "this coexistence led the Macanese to speak Cantonese, the dialect [sic] of the Southern Chinese" (apud RANGEL, 2004, p. 32). Reaffirming the bilingual base is a trait of Macanese, who have always brokered political issues between Portugal and China, as well as in their public administrative functions in serving the Chinese population of Macao.

These excerpts reveal the idea that for the Macanese, Cantonese was a language learned from contact with the "foreigner", which is a misnomer for the citizens of the land. In fact, what this report displays is a huge desire to move away from the Chinese origin and approach the Portuguese heritage at that time. However, this attitude distorts a stubborn reality: Cantonese for every Macanese is even one of the root languages, intertwined and interpenetrating in the moment of relaxation. Recognizing this truth depends on a more intense contact with Macao residents. Talking with them, approaching their truths and collectively constructed truths are 
goals of the mission of the researcher who intends to understand this community.

In addition, there are those who consider themselves "Macao Chinese" and who have gone through a similar process, but in reverse. This is the case of one of the survey's seniors who reported that although he was not an orphan, he had studied in the Western system because, from his parents' perspective, he would guarantee a better future. This Chinese gentleman, 88 years old in 2016, had studied in the college of parents. He reported that he always had a great deal of difficulty with the Portuguese language. His effort, however, secured him a job in the navy's public service. When we met him, he lived in his own flat in Taipa and had a quiet retired civil service life.

\section{The process of integrating Macao into the Chinese political system}

China's decisions regarding the integration of Macao and Hong Kong into the Chinese system have been cautious, for two reasons: (i) an older population is still living in the old system; (ii) a young Mandarin-speaking population formed in the logic of Chinese studies is still being formed. Moreover, there is no way to devise a new logic since the laws and those that elaborate them are not aligned with the central government.

Because of this reality, some essential care is taken daily by China in its steps: (i) to renew legislative and executive positions at every opportunity; (ii) to ensure that Taiwan does not become alarmed at the effects of the resumption of power; (iii) to occupy spaces around Hong Kong and Macao, which often require landfills that in turn, demands time before construction; (iv) to link all Chinese territories by land in order to create a territorial identity and, at the same time, to protect them from invaders; (v) to control virtual networks and other forms of ideological invasion in China, thereby avoiding articulated online contestation. The game is complex and because of this, it has to be played slowly enough in order that the effects are not felt abruptly by society. As such, the motto "A belt and road" draws a connecting line among the Chinese people while strengthening the country's unity around the goals of success and prosperity.

\section{Final Considerations}

Macao (MSAR) is a space in which historical layers have been consolidated, allowing culturally diverse realities to remain in continuous coexistence. In some specific moments, cultural shocks were evident and allowed us to know identities manifesting themselves in demands and claims. Some movements can be recognized from the deictic linkage of the agents, in response to the language policy implemented at the time.

Until 1999, the most general rule in the registries administered by the Portuguese was that everyone should have a Portuguese name, and this act was necessarily preceded by religious 
conversion. Throughout the $20^{\text {th }}$ century, period of this study, the Chinese were atheists, the Portuguese were Catholics. The Portuguese were never a cohesive group, among them, for example, there were the Eurasian (Macanese), who lit incenses for the gods of the East, even though they had participated in the rosary at $6 \mathrm{pm}$ in the local church. These Eurasians constitute a social league, the element that allows dialogue between two very different ethnic groups: the Portuguese and the Chinese. In very few moments, during the time that the Portuguese ruled in Macao, the dynamics of this dialog and co-existence was disrupted, creating identity movements that were silently conceived within the midst of the Chinese and Macanese communities.

If we interpret these dynamics according to the logic of the paradoxes proposed by Givón in order to explain the changes of languages, we can conclude that language is corporeal, language is movement, and it is also action because it manifests cultures in their immateriality. The confounded realities in this Macanese league, in moments of tension, are broken up into two shocking worlds. This configures the paradox of diffuse attention, since identities that overlap and become invisible, in the case of the Eurasians, are segmented between two poles. The most productive decision is illustrated in the context in which one acts without losing the component of one's hybrid root, which is precisely what gives it the flexibility to perform actions in both cultures (paradox of rooting and ease). As a Chinese, one's practice responds outside the Portuguese context and, as a Portuguese, one's practice responds outside the Chinese context. Macanese are the materialization of the superposition of at least two realities. In the tranquility of the city, little is known of this double reality, but it is enough that a typhoon is marked in the distance so that the swinging of the bamboos (CABRAL \& LOURENÇO 1993; CABRAL 1994) can rely on totally paradoxical actions.

\section{References}

AMARO, A. M. Macanese: A changing society. Macao: Review of Culture, p. 213-228, 1994a.

AMARO, A. M. Sons and daughters of the soil. Macao: Review of Culture, p. 12-67, 1994b.

AZEVEDO, R. A. de. A influência da cultura portuguesa em Macau. Lisboa: Instituto de Cultura e Língua Portuguesa/Ministério da Educação, 1984.

BATALHA, G. N. Glossário do Dialeto Macaense: notas linguísticas, etnográficas e folclóricas. Macau: Instituto Cultural de Macau, 1988a.

BATALHA, G. N. Suplemento ao Glossário do dialecto macaense. Macau: Instituto Cultural de Macau, 1988 b.

CABRAL, J. de P.; LOURENÇO, N. Em terra de tufões - dinâmicas da etnicidade macaense. Macau: Instituto Cultural de Macau, 1993. 
CABRAL, J. de P. The 'Ethnic' composition of Macao. Macao: Review of Culture, p. 229-239, 1994.

CARVALHINHOS, P.; ANTUNES, A. M. Princípios teóricos de Onomástica. Toponímia e Antroponímia. O nome próprio. Cadernos do CNLF (CiFEFil), v. XI, p. 108-121, 2007.

CARVALHINHOS, P. Aplicações da teoria dos signos na Onomástica. Língua e Literatura, v. 27, p. 299-309, 2011.

TEIXEIRA-E-SILVA, R.; LIMA-HERNANDES, M. C. Português de/em Macau: traços linguístico-culturais. In: III SIMELP - A formação de novas gerações de falantes de português no mundo. Macau: Universidade de Macau, 2015.

FORJAZ, J. A royal male line (capetigian) in Macao. Macao: Review of Culture, p. 68-83, 1994.

GALANTE, A. de A. B. Henrique de Senna Fernandes: um discurso revelador da literatura e língua de Macau. Dissertação de mestrado. FFLCH/USP, 1999.

GALVÃO, H. \& SELVAGEM, C. Império Ultramarino português: monografia do império. IV volume: Moçambique, Índia, Macau e Timor. Lisboa: Empresa Nacional de Publicidade, 1953.

GASPAR, M. Macanese family genealogies: Memories and identities. Macao: Review of Culture, p. 20-35, 2014.

GIVÓN, T. Context as other minds: the pragmatics of sociality, cognition and communication. Amsterdam/Philadelphia: John Benjamins Publishing Company, 2005.

LIMA-HERNANDES, M. C. Ataúdes linguísticos, saberes locais e consciência sobre o outro. New York: Lincool, v. 2, p. 1-9, 2016.

LIMA-HERNANDES, M. C.; CARVALHINHOS, P. de J.; TEIXEIRA-E-SILVA, R. Nomeação e Baptismo: processos inclusivos na Macau do início do século XX. Review of Culture, RAEM - China, 01 dez, pp. 36-49, 2014.

LIMA-HERNANDES, M. C.; TEIXEIRA-E-SILVA, R. Português de/em Macau: traços linguístico-culturais. In: III SIMELP - A formação de novas gerações de falantes de português no mundo. Macau: Revista de Cultura, 2010.

LIMA-HERNANDES, M. C. A situação da língua portuguesa em Macau. Projeto PQ (CNPq) São Paulo, 2011.

LIMA-HERNANDES, M. C. Constituição da família macaense: uma hipótese para os macaenses 100\%. Projeto de pesquisa estágio no exterior Fapesp, 2015.

LIMA-HERNANDES, M. C. Língua Portuguesa em Macau: amostragem, descrição e organização de dossiê sobre a variedade asiática. Projeto de Pós-Doutorado, 2010. 
LIMA-HERNANDES, M. C.; TEIXEIRA-E-SILVA, R. Anjos de Macau na primeira década do século XX. Fragmentum (UFSM), v. 35, p. 11-15, 2012.

LIMA-HERNANDES, M. C.; TEIXEIRA-E-SILVA, R. No descanso eterno entre lápides e epitáfios: São Miguel Arcanjo e Consolação In: SIMAS, M. (org.) Estudos sobre Macau e outros orientes.1 ed. São Paulo : Editora Paulistana, v.1, p. 128-168, 2017.

MORBEY, J. Aspects of the 'ethnic identity' of the Macanese. Macao: Review of Culture, p. 202-212, 1994.

RANGEL, J.A.H. Falar de nós - I. Macau e a comunidade macaense. Macau: Instituto Internacional de Macau, 2004.

REGO, F. de C. Macau. Macau: Imprensa Nacional, 1950.

ROCHA, R. Português está desaparecendo em Macau. Entrevista concedida à repórter Sílvia Salek no dia 04 de novembro, 2002.”, na BBC Notícias. Disponível em: http://www.bbc.co.uk/ portuguese/noticias/2002/020926_chinamacaurui.shtml. Acesso em 12 de fevereiro de 2010.

SILVA, B. B. da. Cronologia da história de Macau. Macau: Direcção dos serviços de educação e juventude, 1997.

SING, L. L. Generational changes in the cultural atitutes and activities of the people of Macau. Macau: Instituto Cultural de Macau, 1997.

TEIXEIRA-E-SILVA, R.; LIMA-HERNANDES, M.C. Ligas urbanas: traços identitários na trama discursiva de macaenses e paulistas caipiras. Revista de Cultura. Macau: Universidade de Macau, v. 35, p. 34-48, 2011.

TEIXEIRA-E-SILVA, R.; LIMA-HERNANDES, M.C. Políticas linguísticas e língua portuguesa em Macau, China: à guisa de introdução. Signótica, v. 26, p. 61-76, 2014.

TEIXEIRA-E-SILVA, R.; LIMA-HERNANDES, M.C.; SANTIAGO-ALMEIDA, M.M.. Redes sociais e atitudes linguísticas: o caipirês no meio acadêmico. In: SANTIAGO-ALMEIDA, M.M.; LIMA-HERNANDES, M.C. (Orgs.). História do Português Paulista - volume III. 1 ed. Campinas-São Paulo: Publicações IEL-UNICAMP/FAPESP, v. 3, p. 485-497, 2012.

TEIXEIRA-E-SILVA, R.; LIMAHERNANDES, M.C. iṣ̌p Políticas linguísticas para a educação em Macau: uma introdução In: Galvão, V.C. (orgs.) Políticas de promoção e ensino da língua portuguesa ao redor do mundo. Campinas: Pontes Editora, v.1, p. 3360, 2015.

TEIXEIRA, M. The Macanese. Macao: Review of Culture, p. 84-129, 1994a.

TEIXEIRA, M. The origin of the Macanese Macao: Review of Culture, p. 157-161, 1994b. 